DOI https://doi.org/10.18551/rjoas.2018-05.30

\title{
THE ATTITUDE OF KOH NGOMONG OF STATE CIVIL APPARATUS AND WHISTLEBLOWING INTENTION
}

\author{
Purnamasari Anak Agung Sg Intan*, Aryanto Dodik, Wirajaya I Gde Ary, Sudana I Putu \\ University of Udayana, Bali, Indonesia \\ *E-mail: aaintan.ap@gmail.com \\ ORCID: 0000-0002-9303-0828
}

\begin{abstract}
This study analyzes whether the attitude of koh ngomong, subjective norms and the personal cost of reporting influence whistleblowing intention. The theory of reasoned action and the theory of planned behavior are used as the theoretical basis in this research. The population in this study is all the members of the Regional Organization (Organisasi Perangkat Daerah) Denpasar City. The method of determining the sample is purposive sampling. Hypotheses were tested using Partial Least Squares. The results of the analysis show that the attitude of koh ngomong and personal cost of reporting have a negative effect on whistleblowing intentions, while subjective norms have a positive effect on whistleblowing intentions.
\end{abstract}

\section{KEY WORDS}

Whistleblowing, koh ngomong, subjective norm, personal cost of reporting, theory of reasoned action, theory of planned behavior.

Whistleblower is a person (an employee within the organization) who reports allegations of dishonesty, illegal activity or misconduct in government departments, public organizations, private organizations or a company to the public or to powerful officials (Susmanschi, 2012). Whistleblowing has been defined as a disclosure by members of the organization (whether current or not) of an illegal, immoral or illegitimate practice to any person or organization seen as having influence in such a matter (Miceli and Near, 1985). According to Near and Jensen (1983), whistleblowing is a process of influencing someone to use his or her power to change attitudes and behaviors of members of the organization concerned.

Differences in attitude and work behavior are held by each individual, certainly not always in line with the work culture of the organization. Any sophisticated internal control system that is used will not be effective if the human resources that are to implement it turn out to have bad faith or behave unethically.

Unkind or unethical behavior is evidenced by the rampant cases of fraud (corruption) which are committed by the State Civil Apparatus (Aparatur Sipil Negara) as public servants in Indonesia. The detection or eradication of ethical violations in the public sector is not easy to do. Whistleblowing is very effective in exposing fraud and corruption, so it requires community awareness. Disclosure of fraud, otherwise known as whistleblowing in recent years, has also become a phenomenon that attracts the attention of the world and Indonesia.

Indonesia has been shaken with revelations of several cases of fraud successfully revealed by whistleblowers. For example, the case of "Papa Minta Saham (Papa Ask for Stock)". Sudirman Said took the role of whistleblower by reporting Setya Novanto's actions to the Court of Honor Council (Fahlevi, 2017). What Sudirman Said did or whoever took on the role of a whistleblower was an important step to be followed by Indonesian society.

The role of a whistleblower is invaluable in exposing corruption, fraud and mismanagement. The disclosure of initial misunderstandings or the risk of error may then protect human rights, help save lives and enforce applicable law. But unfortunately, the role is not a role that can easily be taken by those who already know the occurrence of an illegal practice. A person who comes from an internal organization will generally face an ethical dilemma in deciding whether to become a whistleblower or to keep it hidden. Some people view whistleblowers as betrayers or people who violate the norms of organizational loyalty, 
others consider whistleblowing a heroic deed that helps to preserve values that are deemed more important than mere loyalty to the organization (Rothschild and Miethe, 1999). This is a conflict that ultimately puts potential perpetrators of whistleblowing in a dilemma, which leads to doubts in determining the attitude that eventually can sway one's intention to be a whistleblower.

The dichotomy in understanding whistleblower conflicts leads studies or research on whistleblowing to be seen from various sciences. The perspective of whistleblowing research from various academic fields, such as psychology (Zhang, Chiu and Wei, 2009), organizational behavior (Seifert et al., 2010), organizational theory (Miceli and Near, 1984), business ethics (Kaptein, 2011) accounting and auditing (Brennan and Kelly, 2007; Miceli, Dozier and Near, 1991) and culture (Hwang et al., 2014).

A study in Indonesia by Soeharjono (2011) and Fatmawati (2016) examined local culture in the context of whistleblowing. Soeharjono (2011) conducted a cultural research bureaucracy "ewuh-pakewuh" on the effectiveness of internal control systems. Meanwhile, Fatmawati (2016) has conducted research on accounting fraud with ewuh pakewuh culture. This attitude can occur because a subordinate will feel uncomfortable or hesitate in expressing contradictory opinions in order to maintain good relations and to avoid conflict with a senior or superior, or someone who is seen as having a higher social standing (Fatmawati, 2016).

In Bali there is a term known as the attitude of koh ngomong, which is the attitude pattern of costiveness, reluctance to speak. This attitude almost resembles the "ewuhpakewuh" attitude that causes adherents to feel reluctant in expressing opinions. The term koh ngomong attitude consists of three syllables. First is attitude. Attitude is a tendency to approach or avoid, respond positively or negatively to various social circumstances (Nikmah, 2014). Secondly, the word koh comes from the Balinese language which means hesitate. Hesitate in the Great Indonesian Dictionary (Kamus Besar Bahasa Indonesia) means lazy (to do something); reluctant to do anything; feel bad; respectful; or there is a feeling of shyness. Thirdly, the term is also derived from the Balinese language which means to speak. So from the explanation, it can be concluded that the attitude of koh ngomong is a tendency of the Balinese which results in a person hesitating, being lazy, reluctant or uncomfortable in expressing a thing or talking.

Dyne, Ang, \& Botero (2003) define the silence of an organization as a collective phenomenon in which employees hold their opinions and concerns about potential organizational problems. They argue that in an organization with a systematic silent culture, employees do not express their ideas and do not speak the truth for fear of negative repercussions and because of the belief that their opinions are unappreciated. Dyne et al. (2003) also revealed there are three motives for employee, i.e. acquiescent silence, defensive silence, and pro-social silence. According to Brinsfield (2012) regarding employee silence motive, silence can occur because someone has known or received much kindness from others, so that person will have difficulty rejecting or ignoring the opinion and request of the person. He undertook to build upon research conducted by Dyne et al. (2003), which revealed that there are 4 (four) employee silence motives: self-protective silence, acquiescent silence, pro-social silence, and deviant silence.

Another consideration that encourages a person to be a whistleblower is the matter of subjective norms. The subjective norm in Theory of Planned Behavior is how far a person has a desire that motivates him to exercise the will or outlook of the person to the behavior he / she will perform (Ajzen, 1991). Ajzen (1991) also states that a person who believes that people in his environment have an influence in his life has the thought that he must perform a certain behavior and he will feel the pressure to carry out the behavior. Conversely, if a person believes that the majority of people within his or her environment have an influence against such behavior, then that person will have the confidence to refuse to carry out the behavior.

The heroism of whistleblowers will certainly never be immune to the ethical dilemmas felt in their working environment. Another influence upon the intention of whistleblowers to engage in whistleblowing is personal cost. Personal cost is the employee's view of the risk of 
retaliation or revenge or sanction from members of the organization, which may reduce the employee's incentive to report wrongdoing. This shows that every employee has a need to protect himself (self-protection) in order to seek security, which is a reason someone does not want to report alleged violations. This is because they are of the view that the reports they make will not be followed up, and they will receive retaliation (revenge). Management will not protect them against the threat of revenge, especially for the type of fraud that involves managers (McMillan et al., 2008). In his research, Bagustianto and Nurkholis (2015) stated that personal cost is not just the impact of retaliation from the offender, but also the decision to be a whistleblower is considered unethical, for example reporting fraud committed by superiors is considered an unethical action because it is against the boss.

The purpose of the study was to prove empirically the influence of the attitude of koh ngomong, subjective norm, and personal cost of reporting on whistleblowing intentions. This research can provide several benefits. First, the theoretical benefits of this research are contributing to the Theory of Reasoned Action and Theory of Planned Behavior and supported by Pro-social Behavior Theory. A positive attitude and support from people around is expected to trigger the emergence of whistleblowing intentions. The discussion on the attitude of koh ngomong (hesitate to speak) in this research is a development of research conducted by Brinsfield (2012) which revealed 4 (four) motives of employee silence.

The Theory of Reasoned Action (TRA) connects belief, attitude, intention and behavior. Intention is determined by subjective attitudes and norms (Ajzen and Fishbein, 1980). Furthermore, TRA developed into the Theory of Planned Behavior (TPB). TRA explains one's intention toward behavior formed by two main factors: attitude toward the behavior and subjective norms (Ajzen and Fishbein, 1980). While in TPB there is additionally one more factor that is perceived behavioral control (Ajzen, 1991).

The attitude of koh ngomong, subjective norm and whistleblowing intention in this research interpret the attitude factor, subjective norm and intention as contained in The Theory of Reasoned Action (TRA). Whereas the personal cost of reporting explains perception of behavioral control or perceived behavioral control as contained in Theory of Planned Behavior (TPB). Pro-social behavior theory is a theory that supports whistleblowing. Brief and Motowidlo (1986) state that whistleblowing is one of thirteen forms of pro-social organizational behavior. This is in line with research conducted by Dozier and Miceli (1985) which states that whistleblowing actions are viewed as pro-social behavior because it will benefit other people (or organizations) as well as benefit the whistleblowers themselves.

Hypotheses:

Attitude of Koh Ngomong and Whistleblowing Intentions. Dyne et al. (2003) revealed that there are 3 (three) motives of employee silence attitude (employee silence motive), i.e. acquiescent silence, defensive silence, and pro-social silence. According to Brinsfield (2012) regarding the employee silence motive, silence can arise due to the individual having known or received much kindness from others so that person will have difficulty to rejecting or ignoring the opinions and requests of the person. Brinsfield (2012) also states that employees may be motivated to withhold unpleasant information from their superiors because they want to protect themselves from the negative impacts associated with whistleblowing.

This silence variable of Dyne et al. (2003) and Brinsfield (2012) is similar to the attitude of koh ngomong in Balinese society. The attitude of koh ngomong can occur due to the age difference factor. Koh ngomong usually will be more often faced by younger people facing older people. Soeharjono (2011) used the ewuh pakewuh culture under high uncertainty conditions that the subordinates will "wait for the superior's guidance" because they feel the boss is more suitable to decide a matter of uncertainty or the issue of ambiguity. Subordinates feel uncomfortable to speak and act because they think it is not their authority. In a pre-condition of the subordinates of "awaiting guidance of the boss", bosses develop a policy of encouraging frank speech from their subordinates.

In general, the Balinese grow up in the tradition of fear of criticizing and being criticized. As much as possible there should be no criticism, for the sake of communal harmony and stability. In that tradition, the criticisms that appear must be muzzled, and the originator of the 
criticism must be hostile. Thus, a Balinese person tends to avoid debate. They will choose silence and do not respond if the conversation has led to the debate so that the attitude of koh ngomong is growing in Bali. Based on the explanation, the first hypothesis (H1) in this study is: intention.

$\mathrm{H}_{1}$ : The higher the person's koh ngomong attitude the lower the whistleblowing

Subjective Norms and Whistleblowing Intentions. The study of Ajzen (1991) states that people have the belief that most people of influence in their lives think that they should behave in a certain manner and that individuals will feel the pressure to do so. Conversely, if people are certain that the majority of other people who influence them do not support them in a behavior, individuals will be confident in refusing such behavior. A study conducted by Randall and Gibson (1991) describes subjective norms affecting the intentions of a health professional to report his colleagues. A study conducted by Ellis and Arieli (1999) on Israeli soldiers also found that subjective norms have a significant effect on the intention of something, while a study conducted by (Miceli, Near, and Graham, 2008) shows that reporters tend to receive support from family and social acquaintances. Similarly, in a study conducted by Park and Blenkinsopp (2009), they found that subjective norms had an impact on whistleblowing intentions of police officers. Keller and Miller (2015) also found that subjective norms have a significant influence on the intentions of an eyewitness in reporting a crime. Purwantini's empirical findings (2016) explain that subjective norms have a positive effect on whistleblowing intentions. Based on the explanation above, the second hypothesis of this study is:

$\mathrm{H}_{2}$ : The higher a person's subjective norm the higher the whistleblowing intention.

Personal Cost of Reporting and Whistleblowing Intentions. The disclosure of fraud will generally have unfavorable consequences for whistleblowers who disclose violations. Elias (2008) reveals that organizations threaten to take revenge on violators to prevent public disclosure of unethical acts of the organization. Personal cost is one example of the need to protect oneself in order to feel safe. Personal cost is also the main reason that people are not interested in reporting allegations of fraud because they assume that their report will be ignored, they will experience revenge, and management will not protect them from the threat of revenge, especially in the type of offense involving managers (McMillan et al., 2008).

One of the considerations for employees who might report fraud is the threat or retaliation of the perpetrators of fraud. The threat of retaliation that may face an employee if disclosing the fraud as described by Kreshastuti (2014), may be retaliation, a threat to security, a transfer to another department that is inconsistent with their competence and would result in an unfair performance assessment. Bagustianto and Nurkholis (2015) say that in view of the risk of this threat of retaliation, the reporting candidate will face a dilemma between doing what is right and suffering the consequences or just silence and pretending not to know what is happening. This dilemma results in an attitude that reduces one's interest to report such fraud. This study was reinforced by Aliyah's (2015) and Kaplan and Whitecotton (2001) studies which stated that personal cost affects whistleblowing intentions. This description leads to the assumption that personal cost of reporting can reduce the employee's intention to report the fraud that he or she knows. The third hypothesis $(\mathrm{H} 3)$ in this study is:

$\mathrm{H}_{3}$ : The higher the Personal cost of reporting borne by someone the lower the whistleblowing intention.

\section{METHODS OF RESEARCH}

The research was conducted at the State Civil Apparatus (Aparatur Sipil Negara) working in the Regional Organizations (Organisasi Perangkat Daerah) in the Government of Denpasar. The research year was 2017. The dependent variable in this research is the whistleblowing intention ( $Y$ ). The independent variables in this study are the attitude of koh ngomong (X1), subjective norm (X2) and personal cost of reporting (X3). 
This study uses primary data sources obtained through questionnaires. The questionnaire used in this study utilized the five point Likert scale. The population of this study were employees of Regional Device Organization (Organisasi Perangkat Daerah) in Denpasar City. The research sample was selected using a purposive sampling technique. A sample of 35 respondents was thereby obtained.

Data analysis technique used in this research is Partial Least Square (PLS). The wake of the established theoretical model is as presented in Table 1. The path diagram of the equation outer model and inner model in this study are as follows:

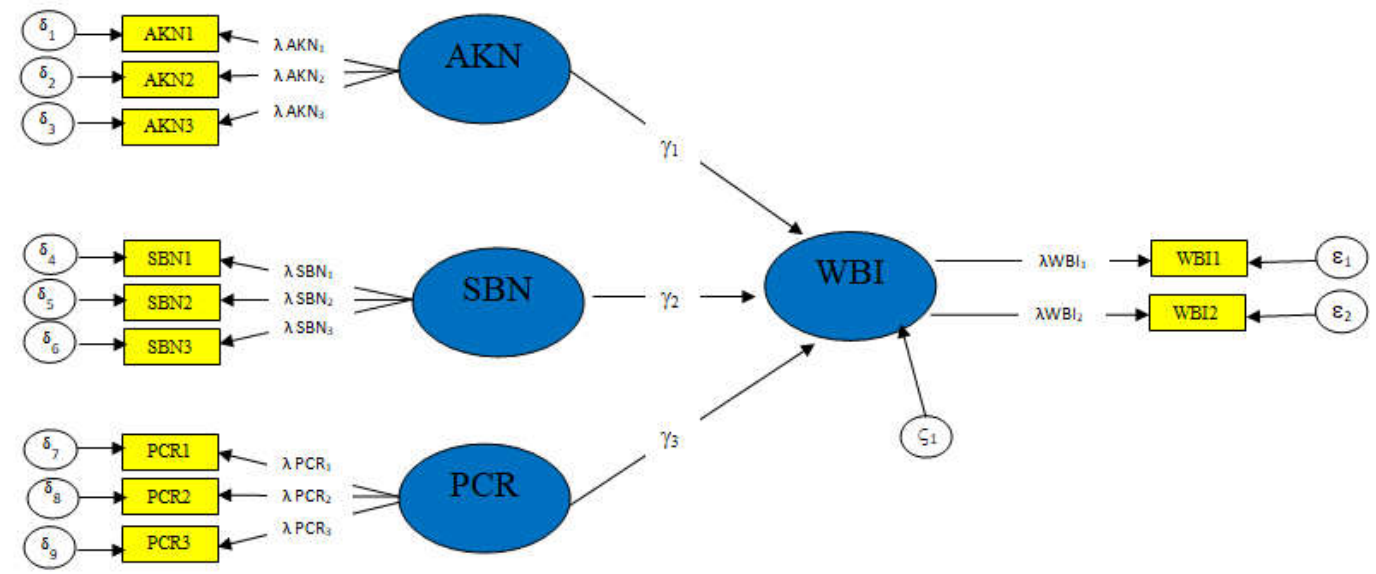

Figure 1 - Path Diagram (Source: Data processed, 2017)

\section{RESULTS OF STUDY}

36 questionnaires were distributed in this study. Of the 36 questionnaires distributed, 35 questionnaires were returned. The questionnaires that are eligible for analysis are 35 questionnaires (with 100\% useable response rate). The questionnaires were filled completely, so they are worthy to be analyzed further. The return of questionnaires can be seen in Table 2.

Descriptive Statistics Analysis. Descriptive statistics in this study are presented to provide information about the characteristics of research variables, including minimum values, maximum values, mean and standard deviation. Based on Table 3 the number of samples of each variable is 35 . The variable of the attitude of koh ngomong is measured using a questionnaire consisting of 9 items of statement. Each statement has a Likert scale of 1 - 5 with a score range of $9-41$. The attitude of koh ngomong has a minimum value of 9.00 which means that there are respondents who disagree on whistleblowing intentions. The maximum value of 41.00 indicates that respondents who answered strongly look favorably on whistleblowing intentions, while the average value of the attitude koh ngomong of 18.46 means the average respondent tends to respond neutrally to the attitude of koh ngomong. The standard deviation value of the attitude of koh ngomong is 7.28 , and is smaller than the mean value, indicating that the attitude of koh ngomong experienced by respondents has small data distribution.

The subjective norm variable was measured using a questionnaire consisting of 6 items of statement with a score range of $8-30$. Subjective norm has a minimum value of 8.00 which indicates that there are respondents who answered disagree. This means there are respondents who believe that whistleblowing intentions are not influenced by superiors, peers and subordinates. A maximum value of 30.00 indicates that there are respondents who answered strongly agree. This means there are respondents who are very confident that the intention of whistleblowing is strongly influenced by superiors, peers and subordinates. The average value of the subjective norm is 22.34 which means the average respondent tends to respond neutrally to subjective norms. The subjective standard deviation value of 4.14 is 
smaller than the mean value; it indicates that subjective norms experienced by respondents have small data distribution.

The personal cost of reporting is measured using a questionnaire consisting of 6 items of statement with a score range of 6 - 30. The personal cost of reporting has a minimum value of 6.00 which indicates that there are respondents who answered disagree. This means that there are respondents who believe that no obstacles are felt in whistleblowing. A maximum value of 30.00 indicates that there are respondents who answered agree. This means that there are respondents who believe that many obstacles are felt in whistleblowing. The average value of personal cost of reporting is 19.91 which means the average respondent tends to respond neutrally to the personal cost of reporting. This means that the standard value of personal deviation cost of reporting, 6.77 is smaller than the mean value. This indicates that the personal cost of reporting experienced by the respondents has small data distribution.

Whistleblowing intentions were measured using a questionnaire consisting of 2 items of statement with a range of $4-10$. Whistleblowing intentions had a minimum value of 4.00 indicating that there were respondents who answered disagree. This means that there are respondents who are not confident about the intention to conduct whistleblowing. The maximum value of 10.00 indicates that there are respondents who answered strongly agree. This means that there are respondents who are very confident about the intention to conduct whistleblowing. The average value of a whistleblowing intention of 8.43 means that the average respondent tends to respond in agreement with whistleblowing intentions. This shows that the average respondent is certain about engaging in whistleblowing. The standard deviation value of whistleblowing intentions of 1.42 is smaller than the mean value; it indicates that the whistleblowing intentions experienced by respondents have small data distribution. The results of the descriptive statistical analysis of this study are presented in Table 3.

Results of the Outer Model Analysis. The results of an outer model value analysis are presented in Table 4. Outer model values or correlations between variables with variables have fulfilled convergent validity because all have a factor loading above 0.5 .

The model is said to have good discriminant validity if each loading indicator of a latent variable is greater correlated with the latent variable than when correlated with other latent variables. Table 5 shows that the loading factor value for each indicator of each latent variable has the largest loading factor value compared to the loading factor value if it is associated with other latent variables. This means that each latent variable has good discriminant validity.

Test results shown in Table 6 show that all values of composite reliability value are greater than 0.70 , the cronbach alpha value is greater than 0.60 and the AVE value in the study has a value greater than 0.50 . Table 6 shows that the composite reliability test shows good and reliable results. All constructs fulfill the composite reliability because the value of each variable is greater than 0.70 . This means that all reflexive indicators are the measuring tools of their respective constructs.

Inner Model Analysis Results. Inner model evaluation or structural model is done to see the relationship between variables, significance value, and the R-square of the research model. The structural model is evaluated by using R-square for dependent constructs, $t-$ tests, and the significance of the structural path parameter coefficients. The structural model is shown in Figure 2.

Inner model test results can show the relationship between constructs by comparing the value of significance and R-square of the research model (Ghozali, 2015: 42). R-square value in Table 7 shows a value of 0.774 which means that 77.4 percent of whistleblowing intent variable can be explained by the variable of the attitude of koh ngomong, subjective norms, and personal cost of reporting, while the remaining 22.6 percent is explained by other variables outside the research. 


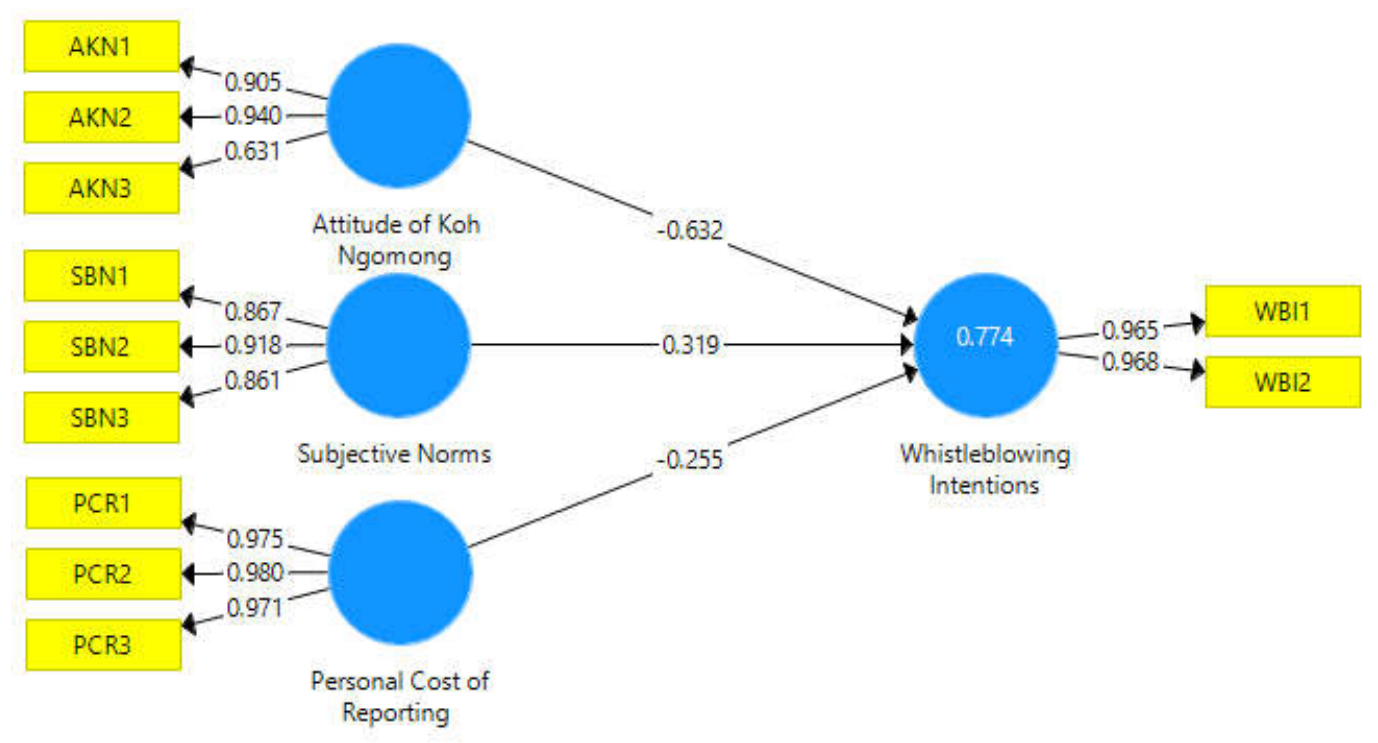

Figure 2 - The structural model (Source: Data processed, 2017)

Hypothesis Testing Results. Hypothesis testing is done by Bootstrap re-sampling method developed by Geisser and Stone (Mindra and Sumertajaya, 2008). The value contained in the result output for inner weight is used to test the hypothesis. The result of $t-$ statistic value on output result for inner weight compared with $P$ Value with $5 \%$ of significance is $\geq 0.05$. The following Table 8 presents the results of the bootstrapping outputs of the effects between variables with statistical analysis of PLS.

Data from Table 8 can be seen that all indicators of the attitude of koh ngomong and personal cost of reporting have a negative and significant relationship to whistleblowing intentions. Whereas the indicator of subjective norm has a positive and significant impact on whistleblowing intentions. The variable having the most influence upon the whistleblowing intention is variable of koh ngomong attitude that is equal to -0,632, compared with the subjective norm variable of only 0,319 and also the variable of personal cost of reporting equal to $-0,255$.

\section{DISCUSSION OF RESULTS}

The Attitude of Koh Ngomong and Whistleblowing Intentions. The first hypothesis states that the higher the attitude of one's koh ngomong attitude the lower the intention of whistleblowing. The results of the test on the parameter coefficient between the attitude of koh ngomong on the whistleblowing intention showed a negative correlation with a coefficient value of -0.632 with $t$-statistic value of 8,530 and significance at $a=0,05$. The value of $t-$ statistics is greater than the value of $P$ value is 0.000 . This means that the attitude of koh ngomong has a negative and significant influence on the intention to engage in whistleblowing, thus the first hypothesis is accepted.

This is in accordance with the Theory of Reasoned Action and Theory of Planned Behavior which states that attitudes toward behavior affect one's intentions in making decisions (Ajzen, 1991). In line with the theory proposed by Ajzen (1991), empirically several studies have proven that the concept of attitude has a relationship to whistleblowing intentions. Soeharjono (2011) also found that the influence of bureaucratic culture "ewuhpakewuh" actually makes the internal control system ineffective. There are things that need to be underlined in the research of Soeharjono (2011), i.e. subordinates feel that there is no value in talking or acting because they deem it outside their authority. In a pre-condition of subordinates "awaiting guidance from superiors", superiors develop policies encouraging blaka attitude (speaking frankly) from the subordinates. Same statement also revealed by Brinsfield (2012) which states that employees may be motivated to withhold unpleasant 
information from their superiors because of the motive to protect themselves from the negative impacts associated with whistleblowing. This means that the attitude of koh ngomong measured in three dimensions, i.e. Pro-social dimension, Acquiescent dimension, and Deviant dimension has a negative and significant influence on whistleblowing intention. The more one believes that the attitude of koh ngomong is the safest attitude, and can protect one from the negative impacts associated with whistleblowing, the smaller the person's intention to become a whistleblower.

The results of this study are in line with Dyne et al. (2003) and Brinsfield (2012) are associated with employee silence motive, which states that employee silence has a significant effect on the behavioral phenomena in the organization. The results of this study are also in line with research conducted by Bjorkelo, Einarsen, Nielsen, \& Matthiesen (2011), Wang \& Hsieh (2013), Elizabeth W. Morrison (2014), and Mannion \& Davies (2015) stated that silence attitude (silence) effects one's intentions. In this case the attitude of koh ngomong is a negative attitude that can lead a person to become a whistleblower. This means that the lower the negative response or negative attitude of a person to the whistleblowing action, the stronger the intention of a person to engage in whistleblowing.

From the test results on each question in the variable of koh ngomong attitude, the question indicator of the Pro-social dimension has a higher value than the values of the acquiescent dimension and the deviant dimension indicators. This indicates that the reason for the koh ngomong attitude of the Head of Finance at the respective Organizations of Regional Device (Organisasi Perangkat Daerah) in Denpasar City is generally due to their wish to avoid conflict that would hurt the feelings of others. They often remain in temporary work to protect their organizations or agencies from dangers and protect others, in this case the colleagues in their work, from danger. While the question on the deviant dimension indicator has a value lower than the other indicators, this means that the attitude of koh ngomong is due to the Head of Finance in the Regional Organizations (Organisasi Perangkat Daerah) Denpasar not wanting to hurt the feelings of others deliberately.

Subjective Norms and Whistleblowing Intentions. The second hypothesis states the higher one's subjective norms the higher the whistleblowing intentions. The test results on the parameter coefficient between subjective norms in Whistleblowing intention showed a positive relationship, with a coefficient value of 0.319 , with t-statistics of 3.654 and significance at $a=0.05$. The value of $t$-statistics is greater than the value of $P$ value, specifically 0.000 . It shows that subjective norms have a positive and significant influence on whistleblowing intentions, thus the second hypothesis is accepted.

The influence of subjective norms on whistleblowing intentions $(\mathrm{H} 2)$ is accepted which states that subjective norms have a positive and significant influence on whistleblowing intentions. This is in accordance with the Theory of Planned Behavior which states that subjective norms have an influence on one's intentions in making decisions (Ajzen, 2005). An individual will intend to do a certain action when associated individuals support that action. This means subjective norms measured by four indicators such as superiors, peers and subordinates have a positive and significant influence on whistleblowing intentions at the Regional Organization (Organisasi Perangkat Daerah) of Denpasar City. The more someone is persuaded that superiors, peers and subordinates support whistleblowing, the bigger someone's intention to engage in whistleblowing.

The results of this study are in line with research conducted by Jubb (1999), Morrison (2014), Mannion \& Davies (2015), Parianti et al. (2016), Purwantini (2016), and Zakaria et al. (2016) which states that subjective norms affect one's intentions. This means that the more confident the nearest person supports becoming a whistleblower, the more likely one is to engage in whistleblowing.

From the test result on each question in the subjective norms variable, support from superiors to engage in whistleblowing has the highest score, then the co-workers indicator is in second position and the subordinate indicator has the lowest value in terms of close environmental support to engage in whistleblowing. Meanwhile, in the case of motivation to conduct whistleblowing, it turns out that the head of Finance at the Regional Organizations 
(Organisasi Perangkat Daerah) Denpasar will consider the motivation derived from colleagues and superiors in comparison with the motivation derived from subordinates.

Personal Cost of Reporting and Whistleblowing Intentions. The third hypothesis states that the higher the cost of personal cost of reporting a person, the lower the intention to engage in whistleblowing. The results of parameter coefficient test between personal cost of reporting on whistleblowing intention showed a negative relationship, with coefficient value of -0.255 with t-statistic value of 2,619 and significance at $a=0,05$. The value of $t$-statistics is greater than the value of $P$ value, specifically 0.009 . This means that the personal cost of reporting has a negative and significant influence on whistleblowing intentions, thus the third hypothesis is accepted.

The influence of personal cost of reporting control on the intention to perform whistleblowing $(\mathrm{H} 3)$ is accepted which states that the personal cost of reporting has a negative and significant influence on the intention to engage in whistleblowing. In this study personal cost of reporting is measured by three indicators such as intimidation, retaliation and negative views. The results of personal cost of reporting show a negative and significant influence on whistleblowing intentions. The more convinced someone is that intimidation, retaliation and negative views are obstacle to becoming a whistleblower, the less intention someone has to engage in whistleblowing. It also means that everyone still has the need for security, so they will try to protect themselves first as stated in the employee silence motive.

The results of this study are in line with research conducted by Mesmer-Magnus \& Viswesvaran (2005) Bjorkelo et al. (2011), Morrison (2014), Aliyah (2015), Bagustianto \& Nurkholis (2015), Mannion \& Davies (2015), and Sonnier et al. (2016) stating that the personal cost of reporting negatively affects the intention of whistleblowing. This means that the higher the belief in the absence of factors that inhibit becoming a whistleblower, the stronger the intention of someone to engage in whistleblowing.

From the test results of each question in the personal cost of reporting variable, the largest compared to other indicators is the retaliation indicator. This means one of the inhibiting factors of whistleblowing is the fear of retaliation. They feel that if they become whistleblowers, then the offender will retaliate. Their next concern is the negative view of colleagues at the agency where they work and also the intimidation in the reporting process. The existence of intimidation, retaliation and negative views are what influence them against becoming whistleblowers.

\section{CONCLUSION AND SUGGESTIONS}

Based on the results of the analysis and discussion, it can be concluded that the attitude of koh ngomong has a negative and significant influence on whistleblowing intentions. This means that the more a person chooses to be koh ngomong or the lower the positive attitude of the State Civil Servant in the Regional Organization (Organisasi Perangkat Daerah) Denpasar, the lower their intention to conduct whistleblowing. Subjective norms have a positive and significant influence on whistleblowing intentions. This means that the higher the subjective norm of a person, the higher the intention of a State Civil Servant in the Regional Organizations (Organisasi Perangkat Daerah) Denpasar City to conduct whistleblowing. Personal cost of reporting has a negative and significant influence on whistleblowing intentions. This means that the more one's beliefs relate to the inhibiting factor for whistleblowing, the weaker the intention of someone to engage in whistleblowing.

Based on the conclusion of the research result, the suggestions submitted to the Local Government of Denpasar City are: to support employees to dare to speak more, without any burden of intervention from their surrounding environment; more frequent coaching of subordinates to understand the personality of each employee better, in order to support whistleblowing without fear or pressure from others; and pay more attention and provide the certainty of legal protection for whistleblowers. To suggest further research: it is to be hoped that other variables may be added, such as the seriousness of fraud, because the results of this study indicate that 77.4 percent of variable intentions of whistleblowing can be explained by the variable attitude of koh ngomong, subjective norms, and personal cost of reporting, 
while the remaining 22.6 percent are explained by other variables outside the study. In addition, in this study, the question items of the attitude of koh ngomong are still described in the context of employee silence motive as found in the study of Brinsfield (2012). Further research development is suggested to reconstruct the question items in the context of Balinese culture. It is also to be hoped that further research will develop the research model using an experimental model and increase the number of research samples by involving employees or other officials as respondents, in order to improve the results.

\section{REFERENCES}

1. Ajzen, I. (1991) 'The Theory Of Planned Behavior. Organizational Behavior And Human Decision Processes.The Theory Of Planned Behavior', Organizational Behavior And Human Decision Processes, Pp. 179-211.

2. Ajzen, I. And Fishbein, M. (1980) 'Theory Of Reasoned Action / Theory Of Planned Behavior', Social Psychology, 2007, Pp. 67-98. Available At: Http://Hsc.Usf.Edu/ Kmbrown/Tra_Tpb.Htm.

3. Aliyah, S. (2015) 'Analisis Faktor-Faktor Yang Mempengaruhi Minat Pegawai Dalam Melakukan Tindakan Whistle-Blowing', Jurnal Dinamika Ekonomi \& Bisnis, 12(2), Pp. 173-189.

4. Bagustianto, R. And Nurkholis (2015) 'Faktor-Faktor Yang Mempengaruhi Untuk Melakukan Tindakan Whistle-Blowing (Bpk Ri)', Jurnal Ilmiah Mahasiswa, 3(1).

5. Bjorkelo, B. Et Al. (2011) 'Silence Is Golden? Characteristics And Experiences Of SelfReported Whistleblowers', European Journal Of Work And Organizational Psychology, 20(2), Pp. 206-238. Doi: 10.1080/13594320903338884.

6. Brennan, N. And Kelly, J. (2007) 'A Study Of Whistleblowing Among Trainee Auditors', British Accounting Review, 39(1), Pp. 61-87. Doi: 10.1016/J.Bar.2006.12.002.

7. Brief, A. P. And Motowidlo, S. J. (1986) 'Prosocial Organizational Behaviors.', Academy Of Management Review, 11(4), Pp. 710-725. Doi: 10.5465/Amr.1986.4283909.

8. Brinsfield, C. T. (2012) 'Employee Silence Motives: Investigation Of Dimensionality And Development Of Measures', Journal Of Organizational Behavior, J. Organiz. Behav. (2012). Doi: 10.1002/Job.

9. Dozier, J. B. And Miceli, M. P. (1985) 'Potential Predictors Of Whistle-Blowing. A Prosocial Behavior Perspective.', Academy Of Management Review, 10(4), Pp. 823-836. Doi: 10.5465/Amr.1985.4279105.

10. Van Dyne, L., Ang, S. And Botero, I. C. (2003) 'Conceptualizing Employee Silence And Employee Voice As Multidimensional Constructs', Journal Of Management Studies, 40(6), Pp. 1359-1392. Doi: 10.1111/1467-6486.00384.

11. Elias, R. Z. (2008) 'Auditing Students' Professional Commitment And Anticipatory Socialization And Their Relationship To Whistleblowing', Managerial Auditing Journal, 23(3), Pp. 283-294. Doi: 10.1108/02686900810857721.

12. Ellis, S. And Arieli, S. (1999) 'Predicting Intentions To Report Administrative And Disciplinary Infractions: Applying The Reasoned Action Model', Human Relations, 52(7), Pp. 947-967. Doi: 10.1177/001872679905200705.

13. Fahlevi, F. (2017) Jaksa Agung Akui Sulit Lanjutkan Kasus 'Papa Minta Saham' Setya Novanto, Tribunnews.Com. Available At: Http://Www.Tribunnews.Com/Nasional/2017/10/27/Jaksa-Agung-Akui-Sulit-LanjutkanKasus-Papa-Minta-Saham-Setya-Novanto (Accessed: 27 October 2017).

14. Fatmawati, R. (2016) 'Budaya Birokrasi Ewuh Pakewuh Dan Kecurangan Akuntansi Di Pemerintahan : Persepsi Aparat Pengawas Internal Pemerintah ( Apip )', Aktual, Vol 2 No 1 Edisi Juni 2016, 2(1), Pp. 20-33.

15. Hwang, D. B. K. Et Al. (2014) 'A Comparative Study Of The Propensity Of WhistleBlowing: Empirical Evidence From China, Taiwan, And The United States', International Journal Of Accounting And Financial Reporting, 3(2), P. 202. Doi: 10.5296/ljafr.V3i2.4723.

16. Jubb, P. B. (1999) 'Whistleblowing: A Restrictive Definition And Interpretation', Journal Of 
Business Ethics, 21, Pp. 77-94. Doi: 10.1023/A:1005922701763.

17. Kaplan, S. E. (2001) 'An Examination Of Auditors' Reporting Intentions When Another Auditor Is Offered Client Employment', Auditing, 20(1), Pp. 44-63.

18. Kaptein, M. (2011) 'From Inaction To External Whistleblowing: The Influence Of The Ethical Culture Of Organizations On Employee Responses To Observed Wrongdoing', Journal Of Business Ethics, 98(3), Pp. 513-530. Doi: 10.1007/S10551-010-0591-1.

19. Keller, P. H. And Miller, M. K. (2015) 'Using The Theory Of Planned Behavior To Predict Crime Reporting Intent. [Electronic Version]', Applied Psychology In Criminal Justice, 11(3), Pp. 193-206. Doi: 10.1007/S10900.

20. Kreshastuti, D. K. (2014) Analisis Faktor-Faktor Yang Mempengaruhi Auditor Melakukan Tindakan Whistleblowing (Studi Empiris Pada Kantor Akuntan Publik Di Semarang). Universitas Diponegoro.

21. Mannion, R. And Davies, H. T. (2015) 'Cultures Of Silence And Cultures Of Voice: The Role Of Whistleblowing In Healthcare Organisations', International Journal Of Health Policy And Management, 4(8), Pp. 503-505. Doi: 10.15171/ljhpm.2015.120.

22. Mcmillan, J. Et Al. (2008) 'Whistleblowing In The Australian Public Sector Enhancing The Theory And Practice Of Internal Witness Management In Public Sector Organisations Foreword', In Whistleblowing In The Australian Public Sector: Enhancing The Theory And Practice Of Internal Witness Management In Public Sector Organisations, P. Ix-+.

23. Mesmer-Magnus, J. R. And Viswesvaran, C. (2005) 'Whistleblowing In Organizations: An Examination Of Correlates Of Whistleblowing Intentions, Actions, And Retaliation', Journal Of Business Ethics, 62(3), Pp. 277-297. Doi: 10.1007/S10551-005-0849-1.

24. Miceli, M. P., Dozier, J. B. And Near, J. P. (1991) 'Blowing The Whistle On Data Fudging: A Controlled Field Experiment', Journal Of Applied Social Psychology, 21(4), Pp. 271295. Doi: 10.1111/J.1559-1816.1991.Tb00521.X.

25. Miceli, M. P. And Near, J. P. (1984) 'The Relationships Among Beliefs, Organizational Position, And Whistle-Blowing Status: A Discriminant Analysis', Academy Of Manaogement Journal, 27(4), Pp. 687-705. Doi: 10.2307/255873.

26. Miceli, M. P. And Near, J. P. (1985) 'Characteristics Of Organizational Climate And Perceived Wrongdoing Associated With Whistle-Blowing Decisions', Personnel Psychology, 38(3), Pp. 525-544. Doi: 10.1111/J.1744-6570.1985.Tb00558.X.

27. Miceli, M. P., Near, J. P. And Graham, J. W. (2008) Whistle-Blowing In Organizations, Administrative Science Quarterly. Doi: 10.2307/2393341.

28. Morrison, E. W. (2014) 'Employee Voice And Silence', Annual Review Of Organizational Psychology And Organizational Behavior, 1(1), Pp. 173-197. Doi: 10.1146/AnnurevOrgpsych-031413-091328.

29. Near, J. P. And Jensen, T. C. (1983) 'The Whistleblowing Process: Retaliation And Perceived Effectiveness', Work And Occupations, 10(1), Pp. 3-28. Doi: 10.1177/0730888483010001001.

30. Nikmah, R. A. (2014) Pengaruh Komitmen Profesional Auditor Terhadap Intensi Melakukan Whistleblowing Dengan Retaliasi Sebagai Variabel Moderating. Universitas Islam Negeri Syarif Hidayatullah.

31. Parianti, N. P. I., Suartana, I. W. And Badera, I. D. N. (2016) 'Faktor-Faktor Yang Memengaruhi Niat Dan Perilaku Whistleblowing Mahasiswa Akuntansi', -Jurnal Ekonomi Dan Bisnis Universitas Udayana, 5(12), Pp. 4209-4236.

32. Park, H. And Blenkinsopp, J. (2009) 'Whistleblowing As Planned Behavior - A Survey Of South Korean Police Officers', Journal Of Business Ethics, 85(4), Pp. 545-556. Doi: 10.1007/S10551-008-9788-Y.

33. Purwantini, A. H. (2016) 'Perilaku Terencana Terhadap Intensi Whistleblowing Internal', Jurnal Ekonomi Syariah, Volume 4(No. 1), Pp. 142-159.

34. Randall, D. M. And Gibson, A M. (1991) 'Ethical Decision Making In The Medical Profession: An Application Of The Theory Of Planned Behavior', Journal Of Business Ethics, 10(2), Pp. 111-122.

35. Rothschild, J. And Miethe, T. D. (1999) 'Whistle-Blower Disclosures And Management Retaliation: The Battle To Control Information About Organization Corruption', Work And 
Occupations, 26(1), Pp. 107-128. Doi: 10.1177/0730888499026001006.

36. Seifert, D. L. Et Al. (2010) 'The Influence Of Organizational Justice On Accountant Whistleblowing', Accounting, Organizations And Society, 35(7), Pp. 707-717. Doi: 10.1016/J.Aos.2010.09.002.

37. Soeharjono, H. I. (2011) 'Pengaruh Budaya Birokrasi "Ewuh-Pakewuh" Terhadap Efektivitas Sistem Pengendalian Intern', Jurnal IImu Administrasi C No. 3 C Volume Viii C Desember 2011, Viii(3), Pp. 243-260.

38. Sonnier, B. M., Lassar, W. M. And Greene, E. (2016) 'An Examination Of The Impact Of An Evidentiary Privilege Protecting Corporate Whistleblowers On Intention To Report Wrongdoing', Journal Of Accounting, Ethics \& Public Policy, Volume 17(No. 2), Pp. 287332.

39. Susmanschi Georgiana (2012) 'Internal Audit And Whistle-Blowing', Economics, Management, And Financial Markets, 7(4), Pp. 415-421.

40. Wang, Y. De And Hsieh, H. H. (2013) 'Organizational Ethical Climate, Perceived Organizational Support, And Employee Silence: A Cross-Level Investigation', Human Relations, 66(6), Pp. 783-802. Doi: 10.1177/0018726712460706.

41. Zakaria, M., Abd Razak, S. N. A. And Yusoff, M. S. A. (2016) 'The Theory Of Planned Behaviour As A Framework For Whistle-Blowing Intentions', Review Of European Studies, 8(3), P. 221. Doi: 10.5539/Res.V8n3p221.

42. Zhang, J., Chiu, R. And Wei, L. (2009) 'Decision-Making Process Of Internal Whistleblowing Behavior In China: Empirical Evidence And Implications', Journal Of Business Ethics, 88(Suppl. 1), Pp. 25-41. Doi: 10.1007/S10551-008-9831-Z.

\section{APPENDIX}

Table 1 - Variable Research Model

\begin{tabular}{cll}
\hline No & \multicolumn{1}{c}{ Construct } & \multicolumn{1}{c}{ Dimensional Construct } \\
\hline 1 & The Attitude of Koh Ngomong & $\begin{array}{l}\text { Prosocial dimension } \\
\text { Acquiescent dimension }\end{array}$ \\
& & Deviant dimension \\
2 & \multirow{2}{*}{ Subjective Norms } & Superiors \\
& & Peers \\
& & Subordinates \\
3 & Personal Cost of Reporting & Intimidation \\
& & Retaliation \\
& & Negative views \\
4 & Whistleblowing Intentions & Whistleblowing tendency \\
& & Decision to do whistleblowing \\
\hline
\end{tabular}

Table 2 - Rate of Return of Questionnaire

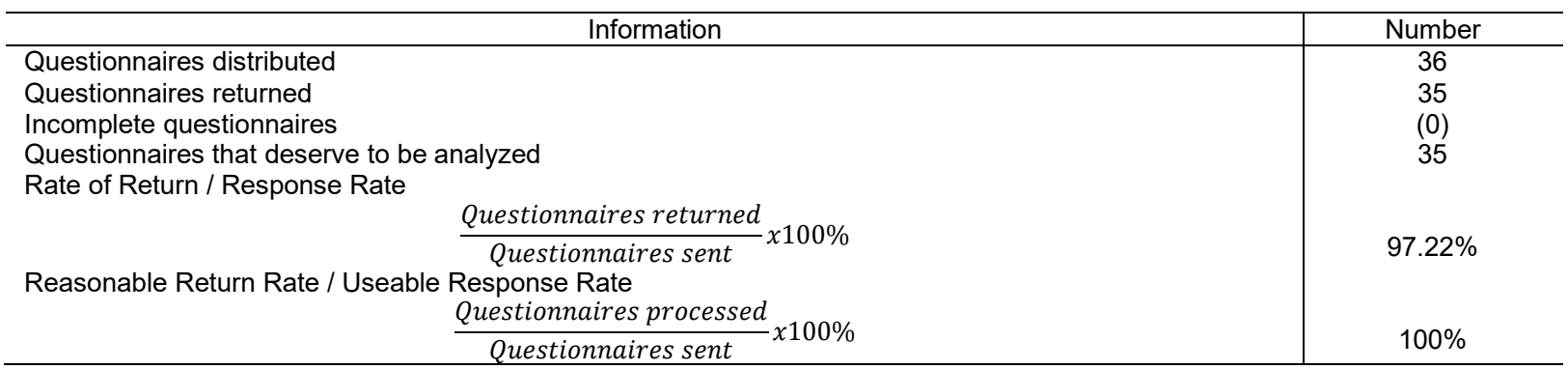

Source: Data processed, 2017.

Table 3 - Descriptive Statistics Test Results

\begin{tabular}{lccccc}
\hline & N & Minimum & Maximum & Mean & Std.Deviation \\
\hline The Attitude of Koh Ngomong & 35 & 9,00 & 41,00 & 18,46 & 7,28 \\
Subjective Norms & 35 & 8,00 & 30,00 & 22,34 & 4,14 \\
Personal Cost of Reporting & 35 & 6,00 & 30,00 & 19,91 & 6,77 \\
Whistleblowing Intentions & 35 & 4,00 & 10,00 & 8,43 & 1,42 \\
\hline
\end{tabular}

Source: Data processed, 2017. 
Tabel 4 - Outer Loadings Results

\begin{tabular}{llcc}
\hline \multicolumn{1}{c}{ Variable } & \multicolumn{1}{c}{ Indicator } & Symbol & $\begin{array}{c}\text { Outer } \\
\text { Loading }\end{array}$ \\
\hline The Attitude of Koh Ngomong & Prosocial dimension & AKN1 & 0,905 \\
& Acquiescent dimension & AKN2 & 0,940 \\
& Deviant dimension & AKN3 & 0,631 \\
Subjective Norms & Superiors & SBN1 & 0,867 \\
& Peers & SBN2 & 0,918 \\
Personal Cost of Reporting & Subordinates & SBN3 & 0,861 \\
& Intimidation & PCR1 & 0,975 \\
& Retaliation & PCR2 & 0,980 \\
Whistleblowing Intentions & Negative views & PCR3 & 0,971 \\
& Whistleblowing tendency & WBI1 & 0,965 \\
& Decision to do whistleblowing & WBI2 & 0,968 \\
\hline
\end{tabular}

Source: Data processed, 2017.

Table 5 - Value Discriminant Validity (Cross Loading)

\begin{tabular}{lcccc}
\hline & $\begin{array}{c}\text { The Attitude of } \\
\text { Koh Ngomong }\end{array}$ & $\begin{array}{c}\text { Subjective } \\
\text { Norms }\end{array}$ & $\begin{array}{c}\text { Personal Cost } \\
\text { of Reporting }\end{array}$ & $\begin{array}{c}\text { Whistleblowing } \\
\text { Intentions }\end{array}$ \\
\hline AKN1 & 0,905 & $-0,451$ & 0,097 & $-0,782$ \\
AKN2 & 0,940 & $-0,214$ & 0,023 & $-0,645$ \\
AKN3 & 0,631 & $-0,028$ & $-0,158$ & $-0,309$ \\
SBN1 & $-0,319$ & 0,867 & $-0,406$ & 0,599 \\
SBN2 & $-0,241$ & 0,918 & $-0,448$ & 0,574 \\
SBN3 & $-0,319$ & 0,861 & $-0,189$ & 0,485 \\
PCR1 & 0,007 & $-0,348$ & 0,975 & $-0,367$ \\
PCR2 & 0,071 & $-0,423$ & 0,980 & $-0,436$ \\
PCR3 & $-0,005$ & $-0,408$ & 0,971 & $-0,363$ \\
WBI1 & $-0,734$ & 0,554 & $-0,361$ & 0,965 \\
WB12 & $-0,706$ & 0,663 & $-0,413$ & 0,968 \\
\hline
\end{tabular}

Source: Data processed, 2017.

Table 6 - Composite Reliability, Cronbach Alpha dan Average Variance Extracted

\begin{tabular}{lccc}
\hline \multicolumn{1}{c}{ Variabel } & $\begin{array}{c}\text { Composite } \\
\text { Reliability }\end{array}$ & $\begin{array}{c}\text { Cronbach } \\
\text { Alpha }\end{array}$ & $\begin{array}{c}\text { Average Variance } \\
\text { Extracted (AVE) }\end{array}$ \\
\hline The Attitude of Koh Ngomong & 0,872 & 0,792 & 0,700 \\
Subjective Norms & 0,913 & 0,858 & 0,779 \\
Personal Cost of Reporting & 0,983 & 0,974 & 0,951 \\
Whistleblowing Intentions & 0,966 & 0,930 & 0,934 \\
\hline
\end{tabular}

Source: Data processed, 2017.

Table 7 - R Square

\begin{tabular}{|l|c|c|c|c|l|}
\hline & $\begin{array}{c}\text { Original } \\
\text { Sample (O) }\end{array}$ & $\begin{array}{c}\text { Sampel } \\
\text { Mean }\end{array}$ & $\begin{array}{c}\text { Standard } \\
\text { Deviation } \\
\text { (STDEV) }\end{array}$ & $\begin{array}{c}\text { T Statistics } \\
(\mid \mathrm{O} / \text { STDEV })\end{array}$ & P Values \\
\hline $\begin{array}{l}\text { Whistleblowing } \\
\text { Intentions }\end{array}$ & 0,774 & 0,792 & 0,065 & 11,972 & 0,000 \\
\hline
\end{tabular}

Source: Data processed, 2017.

Table 8 - Bootstrapping Output Results

\begin{tabular}{lcccc}
\hline & $\begin{array}{c}\text { Original } \\
\text { Sample (O) }\end{array}$ & $\begin{array}{c}\text { t-statistik } \\
(\mid \mathrm{O} / \mathrm{STDEV})\end{array}$ & t-tabel & explanation \\
\hline $\begin{array}{l}\text { The Attitude of Koh } \\
\begin{array}{l}\text { Ngomong } \\
\text { Whistleblowing Intentions }\end{array}\end{array}$ & $-0,632$ & 8,530 & 0,000 & Significant \\
\hline $\begin{array}{l}\text { Subjective Noms } \rightarrow \\
\text { Whistleblowing Intentions }\end{array}$ & 0,319 & 3,654 & 0,000 & Significant \\
\hline $\begin{array}{l}\text { Personal Cost of } \\
\begin{array}{l}\text { Reporting } \Rightarrow \\
\text { Whistleblowing Intentions }\end{array}\end{array}$ & $-0,255$ & 2,619 & 0,009 & Significant \\
\hline
\end{tabular}

Source: Data processed, 2017. 